\title{
Revival of ancient marine dinoflagellates using molecular biostimulatio
}

\author{
Delebecq Gaspard ${ }^{1}$, Schmidt Sabine ${ }^{2}$, Ehrhold Axel ${ }^{3}$, Latimier Marie ${ }^{4}$, Siano Raffaele 4,
}

1 Univ Brest, CNRS IRD, Ifremer, LEMAR F-29280 Plouzané, France

2 UMR5805 EPOC University of Bordeaux 33605 Pessac, France

3 Ifremer, GM F-29280 Plouzané ,France

4 Ifremer, DYNECO F-29280 Plouzané, France

*Corresponding author : Raffaele Siano, email address : Raffaele.siano@ifremer.fr

\begin{abstract}
:
The biological processes involved in the preservation, viability, and revival of long-term dormant dinoflagellate cysts buried in sediments remain unknown. Based on studies of plant seed physiology, we tested whether the revival of ancient cysts preserved in century-old sediments from the Bay of Brest (France) could be stimulated by melatonin and gibberellic acid, two molecules commonly used in seed priming. Dinoflagellates were revived from sediments dated to approximately 150 years ago (156 \pm 27 , $32 \mathrm{~cm}$ depth), extending the known record age of cyst viability previously established as around one century. A culture suspension of sediments mixed with melatonin and gibberellic acid solutions as biostimulants exhibited germination of 11 dinoflagellate taxa that could not be revived under controlled culture conditions. The biostimulants revived some dinoflagellates from century-old sediments, including the potentially toxic species Alexandrium minutum. The biostimulants showed positive effects on germination on even more ancient cysts, showing dose-dependent effects on the germination of Scrippsiella acuminata. Concentrations of 1,10 , and $100 \mu \mathrm{M}$ melatonin and gibberellic acid promoted germination. In contrast, $1000 \mu \mathrm{M}$ solutions, particularly for melatonin, drastically decreased germination, suggesting a potential noxious effect of high doses of these molecules on dinoflagellate revival. Our findings suggest that melatonin and gibberellic acid are involved in the stimulation of germination of dinoflagellate cysts. These biostimulants can be used to germinate long-term stored dinoflagellate cysts, which may promote studies of ancient strains in the resurrection ecology research field.
\end{abstract}

Keywords: Alexandrium, cyst, dinoflagellate, gibberellic acid, melatonin, paleoecology, priming, Scrippsiella, resurrection ecology 
Abbreviations: MEL: melatonin ( $N$-acetyl-5-methoxytryptamine, MEL); GA3: gibberellic acid (7,12-dihydroxy-3-methyl-6-methylene-2-oxoperhydro-4a,7-methano-9b,3-propenoazuleno[1,2b]furane-4-carboxylic) 


\section{INTRODUCTION}

Many organisms have dormant stages in their life cycle during which their development is interrupted (Weider et al. 2018). These dormant life stages help organisms to cope with fluctuating environmental conditions and survive when the environment is temporarily unsuitable for persistence (Hairston et al. 2002, Cáceres and Tessier 2003). Some of these dormant propagules can be stored and accumulate in the environment. In marine sediments, resting stages are observed for marine ciliates (Verni and Rosati 2011), sponges (Simpson and Fell 1974), jellyfish (Kawahara et al. 2013), zooplankton (Radzikowski 2013), and many taxa comprised of phytoplankton such as cyanobacteria (Perez et al. 2017), diatoms (McQuoid et al. 2002, Sanyal et al. 2019), dinoflagellates (Anderson and Rengefors 2006, Ellegaard and Ribeiro 2018), prasinophytes, and haptophytes (Ellegaard et al. 2016).

Marine propagules can be used to determine the effect of environmental changes on marine ecosystems (Dale et al. 1999, Brede et al. 2009, Harnstrom et al. 2011). For instance, the research field of resurrection ecology is based on the revival of organisms in dormant stages that can remain viable for long periods in soils, sediments, ice, and permafrost (Angeler 2007, Orsini et al. 2013, Radzikowski 2013, Houwenhuyse et al. 2018, Sanyal et al. 2019). The term revival is used to designate the germination of seeds, spores, or cysts and/or the hatching of eggs of metazoans. Resurrection ecology approaches assess and compare the genetic and phenotypic responses of past and present populations under controlled conditions (Orsini et al. 2013, Weider et al. 2018). Using these methods, contemporary microevolution of genotypic and phenotypic traits in populations can be effectively assessed over several generations and associated with environmental changes in populations. The most extensively studied resting stages in the marine environments are the viable propagules of diatoms and dinoflagellates. Successful germinations were observed in sediments that are more than a century old for dinoflagellate cysts (McQuoid et al. 2002, Harnstrom et al. 2011, Lundholm et al. 2011, Miyazono et al. 2012, Feifel et al. 2015). A recent study demonstrated the viability and germination of diatom spores in sediments dated up to 7200 years ago (Sanyal et al. 2019). For dinoflagellates in particular, resurrection ecology studies have been constrained by the difficulty of inducing germination in enough individuals to accurately represent a past population. Successful germination of dinoflagellates generally decreases exponentially with depth, as deeper samples contain older cysts (Ellegaard and Ribeiro 2018). Consequently, 
successful germination of an old cyst is rare and very few taxa have been obtained from old biological archives (Lundholm et al. 2011, Miyazono et al. 2012, Feifel et al. 2015).

The germination of dinoflagellates cysts is under both endogenous (maturation and internal clock) and exogenous (environmental factors) control (Anderson and Keafer 1987, Anderson 1998, Perez et al. 1998, Rengefors and Anderson 1998, Matrai et al. 2005). Mandatory dormancy can be alleviated once maturation is complete and the cysts enter a quiescent state during which they can germinate under favorable environmental conditions (Anderson 1998, Lopez et al. 2019). If no germination occurs in response to the environment, dinoflagellate cysts may return to a dormant state through a process named as secondary dormancy (Ficher et al.2018, Lopez et al. 2019). Temperature-mediated induction of secondary dormancy was observed in Pyrodinium bahamense and is thought to be an important factor regulating the seasonal cyst germination pattern of this species (Lopez et al. 2019). Temperature plays a crucial role in alleviating secondary dormancy and synchronizing germination (Fischer et al. 2018, Lopez et al. 2019). Light induction (Binder and Anderson 1986) and oxygen are also required for germination (Anderson et al. 1987, Rengefors and Anderson 1998). The relative contributions of the environmental stimuli to germination success depend on the species, population, and environmental conditions prior to and during the dormancy period (Anderson and Keafer 1987, Anderson et al. 1987, Montresor and Marino 1996, Hallegraef et al. 1998, Fischer et al. 2018, Lopez et al. 2019). Thus, identifying the optimal conditions that revive dormant cysts remains challenging (Fischer et al. 2018, Weider et al. 2018, Lopez et al. 2019). Experimental incubation conditions and the stimuli used in revival experiments to induce germination may limit the germination success of old cysts. Indeed, the observation of potentially viable resting stages in sediments older than their maximal germination record supports the idea that germination of resting cysts depends on unknown biological and/or abiotic factors (Lundholm et al. 2011).

Various techniques have been used to improve the success of seed germination and egg hatching in studies conducted for i) understanding the processes of perception, integration, and signal transduction and ii) synchronizing germination or hatching when optimal conditions for germination or hatching were not fulfilled (e.g., Lavens and Sorgeloos 1987, Dumont et al. 1992, Costas et al. 1993, Hagiwara et al. 1995, Ibrahim 2016). Examples of approaches using chemicals that accelerated or increased seed germination or egg hatching success are shown in Table 1. Methods for priming of plants were developed in the crop science field to enable rapid, massive, and synchronous germination (Née et al. 2017). Specific treatments can be used to increase seed 
germination success (Finkelstein et al. 2008), reduce potential stress pressure (Posmyk et al. 2009, Zhang et al. 2014), and reduce aging effects in seeds (Deng et al. 2017a). In crustacean and rotifer eggs, specific treatments such as desiccation or osmotic shock were found to improve the hatching rate of the eggs (reviewed in Lavens and Sorgeloos 1987). Specific chemicals (e.g., acetate, auxin, and gibberellic acid) were found to stimulate spore germination in Cyanophyceae (Anabaena sp.), Chlorophyceae (e.g. Chlamydomonas sp., Stigeoclonium pascheri), Ulvophyceae (Pithophora oedogonia, Ulva sp.), and Xanthophyceae (Vaucheria sp.; reviewed in Agrawal 2009). Growth factors were found to increase cyst excystment in Alexandrium tamarense (Costas et al. 1993).

This study was conducted to examine the maximal longevity of dinoflagellate cysts in natural sediment archives. According to studies carried out in other organisms, we tested dinoflagellate cyst germination using a priming approach by applying biostimulants that might facilitate revival. Based on previous studies, we selected two candidate molecules to treat dinoflagellate cysts, melatonin (( $N$-acetyl-5-methoxytryptamine, MEL) and gibberellic acid (7,12dihydroxy-3-methyl-6-methylene-2-oxoperhydro-4a,7-methano-9b,3-propenoazuleno[1,2b]furane-4-carboxylic, GA3), which are involved in life-cycle transitions of many organisms (Balzer and Hardeland 1996, Achard and Genschik 2009, Arnao and Hernández-Ruiz 2014). MEL production has been observed in dinoflagellates, and the enzymes responsible for its biosynthesis have been identified (Hardeland and Poeggeler 2003). In dinoflagellates, endogenous MEL levels show a circadian pattern in Lingulodinium polyedra (Poeggeler et al. 1991) and MEL is involved in the formation of pellicle cysts (Wong and Wong 1994). Gibberellic acid was predicted to be involved in cell elongation in Chlorella minutissima (Stirk et al. 2014) and stimulates cell division in the diatom Cyclotella cryptica (Adair and Miller 1982) and dinoflagellate Karenia brevis (cited as Gymnodinium breve in Paster and Abott 1970). Although studies have shown that melatonin and gibberellic acid are involved in dinoflagellate metabolism, their roles in reactivating metabolism and inducing germination in long-term buried resting cysts have not been examined.

\section{MATERIAL AND METHODS}

\section{Sample collection}

A sediment core (KS03) was collected on April 25, 2017, from the Bay of Brest (Brittany, France; $48^{\circ} 22^{\prime} 57.60^{\prime \prime} \mathrm{N}-04^{\circ} 26^{\prime} 49.80^{\prime \prime} \mathrm{W}$ ) at a water depth of $7.80 \mathrm{~m}$ on-board the R/V Thalia using a 
Kullenberg core sampler. The sediment core was collected near Brest harbor in a non-dredged zone with a low sedimentation rate. This area was chosen for collection because it contained a sediment core spanning the longest possible time period. Sampling was performed near the cores KS01 (10 m away) and KS05 (180 m away). The sediment core (3.32 m long) was immediately extruded from the Plexiglas tube and sliced into 1-cm layers. To avoid contamination across sample layers, only one in two slices was used for subsampling and further analyses. The external sediments (i.e., those in contact with the Plexiglas tube) were discarded to avoid contamination by sediment potentially displaced by the coring tube extrusion process. Approximately $10-20 \mathrm{~g}$ sediment samples were collected from the remaining material for cyst germination and stored in $50-\mathrm{mL}$ Nalgene tubes at $4^{\circ} \mathrm{C}$ in the dark and without oxygen, until germination experiments were conducted. Additional sediment subsamples of $>10 \mathrm{~g}$ were collected for short-lived radionuclide dating. Shells of gastropods were isolated from the sediments for ${ }^{14} \mathrm{C}$ dating.

\section{Sediment dating}

Recent (100-150 y) core chronology was established for the experimental core KS03 using depth profiles of excess ${ }^{210} \mathrm{~Pb}\left({ }^{210} \mathrm{~Pb}_{\mathrm{xs}}\right)$, a naturally-occurring radionuclide, and ${ }^{137} \mathrm{Cs}$, an artificial radionuclide, as described by Schmidt et al. (2007). The presence of shellfish debris, including maerl, made gamma measurements difficult. First, the coarse carbonate fraction was sorted and removed. The remaining fine carbonate fraction diluted the radioelement contents, with long counting times ranging from 24 to $126 \mathrm{~h}$ per sample. The activities $\left(\mathrm{mBq} \cdot \mathrm{g}^{-1}\right)$ of ${ }^{210} \mathrm{~Pb},{ }^{226} \mathrm{Ra}$, ${ }^{234} \mathrm{Th}$, and ${ }^{137} \mathrm{Cs}$ were measured in $\sim 10 \mathrm{~g}$ of dry sediment using a Mirion Energy Broad Energy (BEGe, Mirion Technologies, San Ramon, CA, USA) $\gamma$ detector, which presents detection efficiencies and energy resolution optimized in the 3-662 keV energy regions, where gamma energies of interest are located. The detector was calibrated using certified reference material from the International Atomic Energy Agency (RGU-1; RGTh; SOIL-6). Activity errors were based on 1 standard deviation counting statistics. Excess ${ }^{210} \mathrm{~Pb}\left({ }^{210} \mathrm{~Pb}\right.$ xs $)$ was calculated as the difference between the measured ${ }^{210} \mathrm{~Pb}$ and ${ }^{226} \mathrm{Ra}$ activities. The two first layers of the core were measured twice at a few days and several months after sampling to detect excess ${ }^{234} \mathrm{Th}$, a short-lived radionuclide $\left(\mathrm{T}_{1 / 2}=24.1 \mathrm{~d}\right)$, which is a tracer of a good recovery of the uppermost sediment and of bioturbation (Schmidt et al. 2007). 
Dating of ancient sediments ( $>150$ years) was performed by analyzing ${ }^{14} \mathrm{C}$ in gastropod shells (Bittium spp., Crisilla spp., Hydrobia spp., Jujubinus spp., Rissoa spp.; total weight of each sample $<10 \mathrm{~g}$ ) collected from the sieved sediment. ${ }^{14} \mathrm{C}$ dating was carried out on the experimental core $\mathrm{KS} 03$ and on core $\mathrm{KS} 05$ for comparison. KS05 and KS01 were divided into layers and constituted a chrono-stratigraphic referential for KS03. ${ }^{14} \mathrm{C}$ analyses were conducted at the Poznań Radiocarbon Laboratory (Poznań, Poland). Absolute dating was corrected for the mean ${ }^{14} \mathrm{C}$ age difference between the atmosphere and oceanic surface waters by applying a reservoir correction (R) of $325 \mathrm{y}$ (Tisnérat-Laborde et al. 2010) with an applied regional deviation (DR) for the bay of Brest of 46 y (Gregoire et al. 2017). The results of absolute dating were then calibrated using Calib Rev 7.0.4 software (Stuiver and Reimer 1993) from the "Intcal13" calibration curve (Reimer et al. 2013), with a confidence level of $95 \%$ for the standard deviation (sigma 2). Radiocarbon dates were calculated for 3 gasteropod samples of KS03 cores and, for comparison, on 4 gasteropod samples of KS05. The data presented in this study allowed the geological history of core KS03 to be described until approximately 800 years before present (or until around 1100 years $\mathrm{AD})$.

\section{Germination experiments}

Germination experiments were carried out on the experimental core KS03. Subsamples of variable volumes were collected from the original collection tubes and places in new sterile 50 -mL tubes. Autoclaved and filtered $(0.2 \mu \mathrm{m})$ seawater from the sampling site was added to the tubes, and the resulting slurry was gently sonicated in a cooled ultrasonic bath (Ikon Industries, Chino, CA, USA) for 9 min to disaggregate sediment particles and unbind cysts from the sediments. The samples were washed with the same seawater and sieved though metal and nylon mesh sieves of 100 and $25 \mu \mathrm{m}$, respectively, to collect resting stages of $25-100 \mu \mathrm{m}$. This material was finally resuspended in filtered seawater from the sampling site. A volume of $250 \mu \mathrm{L}$ ( $\sim 80 \mathrm{mg}$ of wet weight of sediment) of this fractionated sediment mix was deposited in each well of 12-well plastic plates filled with $3 \mathrm{~mL}$ of different experimental and control media.

Experimental solutions of MEL (Sigma-Aldrich, St. Louis, MO, USA) and GA3 (Dutscher, Cedex, France) used to optimize cyst germination were obtained by diluting subvolumes of mother solutions in 5-fold diluted $\mathrm{K}$ medium (K/5; Anderson et al. 2005) just before starting the germination experiments. All solutions contained the same amount of solvent (final dimethyl 
sulfoxide concentration of $0.5 \%, \mathrm{v} / \mathrm{v})$. Control media consisted of solutions containing either i) $\mathrm{K} / 5$ and $0.5 \%$ dimethyl sulfoxide (v/v) and ii) only $\mathrm{K} / 5$.

The experimental plates were sealed to reduce evaporation and then incubated at $16^{\circ} \mathrm{C}$ in the dark for the first $12 \mathrm{~h}$ to ensure sufficient time for MEL to act, as it is known to be photolabile (Andrisano et al. 2000). The plates were exposed to $80 \mu \mathrm{mol}$ photons $\cdot \mathrm{m}^{-2} \cdot \mathrm{s}^{-1}$ in $16: 8 \mathrm{~h}$ light:dark cycles at $16^{\circ} \mathrm{C}$. Dinoflagellate vegetative cell germination was carefully monitored daily under an inverted microscope (Zeiss Axiovert 135, Oberkochen, Germany) from the third day after starting the experiment until 28 days. Germination experiments were conducted from 9 to 17 months after core sediment sampling and slicing.

The effect of two concentrations of MEL and GA3 $(100$ and $1000 \mu \mathrm{M})$ was tested on dinoflagellate cysts from different depth layers $(3,23,31,41$, and $49 \mathrm{~cm})$. This first experiment was designed to identify: i) species potentially reacting to the biostimulant treatments, ii) the maximal depth at which germination was possible, and iii) the sediment depth where the germination potential was high enough to quantify the dose-dependent effect of the two hormones on cyst germination.

The dose-dependent effects of MEL and GA3 were tested in a second experiment performed on sediment collected from a depth of $23 \mathrm{~cm}$, where germination potential and germinating cyst diversity were high. Four different concentrations $(1,10,100$, and $1000 \mu \mathrm{M})$ of the two biostimulant solutions were tested for each molecule. For concentrations of 100 and 1000 $\mu \mathrm{M}$, the results of the two experiments were pooled.

For each taxon, germination was recorded as soon as a live, motile vegetative dinoflagellate cell was observed. The method used in this study did not allow for precise quantitative estimation of cyst germination rates. However, this approach minimizes both the damage caused by manipulating cysts and potential bias linked to cyst selection (McQuoid et al. 2002, Lundholm et al. 2011).

\section{Taxa identification}

The taxonomic assignment of germinated dinoflagellates was performed as precisely as possible by light microscopy (shape identification, swimming behavior observations, plate tabulation reconstruction for thecate dinoflagellates). Autotrophic species were distinguished from heterotrophic species based on the presence of cell pigmentation. Some taxa were identified at the 
species level (i.e., Alexandrium minutum), whereas others were assigned to genera (i.e., Protoperidinium spp.), taxonomic groups (i.e., Diplopsalis group, Gymnodiniales $<20 \mu \mathrm{m}$ ), or listed as different forms (i.e., unknown heterotrophs 1, 2). Precise taxonomic assignations were not possible in many cases because monoclonal cultures could not be obtained for germinated dinoflagellates despite isolation attempts. Monoclonal strains were successfully established for Scrippsiella spp., which was the most successfully germinated taxon. These strains were genetically identified as described by White at al. (1990). Briefly, total genomic DNA was extracted using a DNEasy plant mini kit (Qiagen, Hilden, Germany), and the entire internal transcribed spacer of the ribosomal DNA region was amplified by polymerase chain reaction using universal primers developed by White et al. (1990). Amplified products were purified (QIAquick PCR purification kit, Qiagen) and sent to GATC Biotech (https://www.eurofinsnomics.eu/en/custom-dna-sequencing/gatc-services/) for Sanger sequencing. After quality control, all sequences were analyzed on the National Center for Biotechnology Information website (https://www.ncbi.nlm.nih.gov/) using the tool Nucleotide Blast. All Scrippsiella spp. strains were unambiguously identified as S. acuminata (formerly Scrippsiella trochoidea) according to the classification described by Kretschmann et al. (2015). The phylogenetic assignation of germinated strains was beyond the scope of this work and therefore the results are not shown here.

\section{RESULTS}

\section{Chronological reconstruction of the sampled core}

The chronology of the sediment core was reconstructed by combining two complementary approaches, the ${ }^{210} \mathrm{~Pb}_{\mathrm{xs}}$ profile to reconstruct the recent core chronology $(<150 \mathrm{y})$ and ${ }^{14} \mathrm{C}$ shell dating for the older timeline. The ${ }^{210} \mathrm{~Pb}_{\mathrm{xs}}$ profile revealed significant activities in the top core, followed by a rapid decrease to negligible values at greater depths to $22 \mathrm{~cm}$ in the sediment (Fig. 1). Excess ${ }^{234} \mathrm{Th}$ was detected, demonstrating good recovery of the surface sediment, but only in the uppermost layer of the core $\left(22 \pm 5 \mathrm{mBq} \cdot \mathrm{g}^{-1}\right)$. Along with the absence of a mixed layer in the

${ }^{210} \mathrm{~Pb}_{\mathrm{xs}}$ profile, these results indicate that there was no significant mixing (bioturbation) of the deposited sediment. Based on the constant flux constant sedimentation model, a mean sedimentation accumulation rate of $0.20 \pm 0.04 \mathrm{~cm} \cdot \mathrm{y}^{-1}$ model was derived from the ${ }^{210} \mathrm{~Pb}_{\mathrm{x}}$ profile. 
Sediment ages were estimated down to $32 \mathrm{~cm}(=156 \pm 27$ y old sediments or $1861 \pm 27$ AD; Fig.

1) considering the sedimentation rate and the age of the top sediments. The activities of ${ }^{137} \mathrm{Cs}$ were low. ${ }^{137} \mathrm{Cs}$ was detected beginning at approximately $12 \mathrm{~cm}$, corresponding to the first introduction of artificial ${ }^{137} \mathrm{Cs}$ in the environment in the early $1950 \mathrm{~s}$ and validating the chronological framework based on ${ }^{210} \mathrm{~Pb}_{\mathrm{xs}}$. Radiocarbon $\left({ }^{14} \mathrm{C}\right)$ ages were calculated at 42 and $50 \mathrm{~cm}$ (Table $\mathrm{S} 1$ in the Supporting Information). The ${ }^{14} \mathrm{C}$ results showed a gap in dating between the recent sedimentation developed from the middle of the 19th century, estimated by ${ }^{210} \mathrm{~Pb}_{\mathrm{xs}}$, and old deposits dated from the central middle age. These results suggest the presence of an erosive surface in our sediment deposits, as confirmed by analyses of cores KS01 and KS05 (Fig. S1 in the Supporting Information).

\section{Biostimulation of dinoflagellate germination}

In the first experiment, two concentrations of MEL and GA3 (100 and $1000 \mu \mathrm{M})$ were applied to dinoflagellate cysts from different depth layers $(3,23,31,41$, and $49 \mathrm{~cm})$ to i) determine the maximal depth at which germination was possible and ii) identify the deepest sediment layer where a sufficiently large number of germinated cells could allow further experiments. Successful dinoflagellate revival observed under both non-stimulated culture conditions and following treatment with 100 and $1000 \mu \mathrm{M}$ MEL and GA3 are shown in Figure 2. Motile vegetative cells were observed down to $49 \mathrm{~cm}$ in sediments dated beyond $156 \pm 27$ years ago. Scrippsiella acuminata cells quantitatively dominated germinations (59-84\%) in sediments dated to $117 \pm 21 \mathrm{y}$ ago (at a depth of $23 \mathrm{~cm}$; Figs. 2-4, Table S2 in the Supporting Information). Germination success at depths greater than $23 \mathrm{~cm}$ was greatly reduced, with only two successful germinations from sediments at $31 \mathrm{~cm}$, one at $41 \mathrm{~cm}$, and one at $49 \mathrm{~cm}$. Scrippsiella acuminata was the only taxon revivified from sediments at these depths. Its germination was possible only after treatment with $100 \mu \mathrm{M}$ MEL and $100 \mu \mathrm{M}$ GA3.

Based on these results, experimental efforts were subsequently focused on the $23-\mathrm{cm}$ depth layer of sediment which was the deepest layer tested and showing high levels of successful cyst germinations. To identify the biostimulant concentrations giving the best germination success, a higher volume of sediment in this layer was tested (total of $17.5 \mathrm{~g}$ ) and all MEL and GA3 treatments were used. The number of germinated cells was divided by the number of wells investigated for each condition to compare the experimental treatments. Except for $1000 \mu \mathrm{M} \mathrm{GA} 3$ and MEL, all treatments yielded a larger number of germinated cells per well than that observed 
under control conditions (Fig. 3). The number of cells germinated per well under control conditions was nearly double that observed at $100 \mu \mathrm{M}$ MEL and $10 \mu \mathrm{M}$ GA3.

Precise taxonomic assignment was not always possible to the species level using light microscopy. In most cases, the revived taxa were observed for a few seconds before cells became hidden in the sediments. Species, genera and group identifications were possible on the basis of some morphological characters appreciable in these conditions (shape, size, swimming behavior, theca presence or absence, theca tabulation of died cells, pigmentation). Hence, the species Alexandrium minutum, Heterocapsa minima, Margalefidinium polykrikoides, the genus Protoperidinium spp., the group Diplopsalis, and the taxa undet. Gymnodiniales $20<\mathrm{x}<50$, unknown autotroph and unknown heterotroph were identified morphologically at light microscopy (Figs. 2, 3). Most germinated dinoflagellates were assigned to Scrippsiella acuminata (Figs. 2, 3). This species-specific identification was possible both to morphological observations (shape, pigmentation, size) and thanks to the results obtained from Sanger sequencing of the cultures established from some germinated cells. Scrippsiella acuminata cultures were the only obtained in this study, so genetic species identification was only possible for this species.

In addition to Scrippsiella acuminata, Protoperidinium spp. and taxa belonging to the Diplopsalis group were revived in nearly all treatments (Fig. 3). Other taxa germinated much less frequently and sometimes only once (Table S2). Taxa such as Margalefidinium polykrikoides, Alexandrium minutum, Heterocapsa minima, and Gymnodiniales and heterotrophic dinoflagellates germinated only once and only when treated with biostimulants, despite the larger amount of sediment processed. Given the high germination success obtained for S. acuminata, we selected this species to evaluate the effect of biostimulant concentrations on cyst germination.

\section{Dose-dependent effect of biostimulant treatment on germination patterns}

To identify the germination patterns under different hormone treatments, we calculated the number of wells in which cells of Scrippsiella acuminata germinated each day compared to the total number of experimental wells (percentage of wells positive for germination). The cumulative percentages of germination were plotted versus time of the experiment (Fig. 4). The first germinations were observed from the first day of observation ( $3^{\text {rd }}$ day from the beginning of the experiment) after all melatonin treatments and in the control condition. The cumulative percentage of germination of samples treated with 1 and $10 \mu \mathrm{M}$ MEL was immediately higher compared to that of the control condition. The cumulative percentage of germination was lower in the control 
condition than in all treatments; for 1 and $10 \mu \mathrm{M}$ on the first day of observation and $100 \mu \mathrm{M}$ treatment on day 10. The highest cumulative percentage of germination was obtained 13-14 days after beginning the experiment for 1, 10, and $100 \mu \mathrm{M}$ MEL. Germinations increased over time with $1000 \mu \mathrm{M}$ MEL treatment, but their cumulative percentages were lower than those of both other treatments and the control condition throughout the experiment (Fig. 4). For all GA3 treatments, the first germinations were observed from the first day of observation (day 3 from the beginning of the experiment). All treatments slightly accelerated the germination of S. acuminata compared to control conditions. The highest cumulative percentages of germination were obtained on different days of treatments from days 6 to 18 day of the experiment. Under control conditions, the highest cumulative percentages of germination were observed after day 21 of the experiment.

\section{DISCUSSION}

We successfully applied biostimulants to revive dinoflagellate cysts buried for more than a century in sediments. MEL and GA3 as biostimulants revived dinoflagellates from cysts buried for approximately 150 y (32 cm in our core depth; $156 \pm 27$ y ago), both increasing the diversity of species potentially revivable from sediments and further extending the limits of germination potential of dinoflagellates, which has been limited to $100 \mathrm{y}$. These findings may promote studies in the field of resurrection ecology, which are currently limited by the number of viable cysts in sediment samples and sediment depth (age) at which their germinations are possible (Ellegaard et al. 2018, Weider et al. 2018).

\section{Diversity of revivable marine dinoflagellates using biostimulants}

Our experiments allowed the germination of 15 marine dinoflagellate taxa from century-old sediments (with and without biostimulants); in previous studies, only one taxon was germinated from century-old sediments (Lundholm et al. 2011, Miyazono et al. 2012, Kremp et al. 2018). The number of taxa revived may have been underestimated, as germination experiments were performed 9-17 months after sediment core sampling. The germination success of some taxa from old sediments can be reduced over longer sample storage times. For instance, Lundholm et al. (2011) showed that Lingulodinium polyedra (cited as Lingulodinium polyedrum) cysts were unable to germinate after 300-450 d of storage, although its germination success was $20-50 \%$ in 
the first $50 \mathrm{~d}$. The authors suspected that oxygen exposure during core slicing negatively affected the success of cyst germination. In contrast, no effect of duration of storage was observed on Scrippsiella spp. and Pentapharsodinium dalei cysts in this study, indicating that cyst viability during storage depends on the species (see for example Lundholm et al. 2011).

Under normal culture conditions (without biostimulation), we successfully germinated a dinoflagellate belonging to the Diplopsalis group and species attributed to Protoperidinium spp. The oldest cysts of these genera known to germinate were 10-15 y old (Lundholm et al. 2011). For Scrippsiella spp., former maximal survival was reported to be 60 years on the northwest coast of the USA (Feifel et al. 2015) and 40 years on the Swedish west coast (Lundholm et al. 2011). Here, we showed that under normal culture conditions, S. acuminata may be revived from sediments approximately 150 years old.

Addition of MEL and GA3 to the sediment resuspensions allowed for the revival of 11 dinoflagellate taxa (e.g., Alexandrium minutum, Margalefidinium polykrikoides, Gymnodinium sp., Heterocapsa minima) which did not germinate under normal culture conditions. In addition, $A$. minutum and $H$. minima were revived from ancient (approximately 117 years old) sediments only through the application of biostimulants. The potentially toxic dinoflagellate A. minutum was previously reported to germinate from sediments dating back to the 1990s in the Bay of Brest (Klouch et al. 2016a). Here, we found that MEL revived this species from much older sediments from the same area. Therefore, A. minutum cysts remained viable in at least $31-\mathrm{cm}$-deep sediments from the Bay of Brest. This repository of viable cysts represents a potential source of harmful algal bloom initiation in case of sediment resuspension due to anthropogenic sediment dredging during harbor development works, as already proposed in Klouch et al. (2016b).

The higher germination success of Scrippsiella acuminata compared to other species may be explained by the coincidence between the application of biostimulants and seasonal dormancy cycling of this species. Excystment in dinoflagellates can display a seasonal pattern, as demonstrated for species belonging to the Alexandrium genus (Kim et al. 2002, Fischer et al. 2018) and Scrippsiella genus (Ishikawa and Taniguchi 1996, Kim and Han 2000). Our experiments were conducted from March to September, and the applied biostimulants may have affected specific metabolic pathways already activated for seasonal germination of the species. The higher germination success induced by specific biostimulant concentrations compared to in control experiments suggests that MEL and GA3 accelerated and/or promoted the germination of S. acuminata. In contrast, biostimulation was not successful in germinating some species possibly 
because their cysts were still in their seasonal dormant status at the time the experiment was conducted. Based on the coincidence between seasonality and germination under biostimulation, the effects of MEL and GA3 may be underestimated. These molecules should be tested during other periods of the year on the same sediment samples or on sediments collected from other ecosystems to determine whether their positive stimulation effects varied according to the seasonal dormancy cycle of dinoflagellates and whether their application is limited to dinoflagellate communities in specific environments. After germination, $S$. acuminata was the only species that grew under our experimental conditions. Germinated cells of $S$. acuminata exhibited mitotic division, likely because the experimental conditions (nutrient concentrations, light intensity, photoperiod, and temperature) after germination, as well as the physiological status of this species, were favorable for cell growth, which eventually led to establishment of a monoclonal culture only for S. acuminata. This suggests that MEL and GA3 biostimulants can promote the germination of long-term buried cysts; however, growth of the revived species depends on the species-specific culture and physiological conditions.

\section{Survival time of viable dinoflagellate cysts in marine sediments}

Through chemical biostimulation, we germinated a few cells in sediments dated to the central middle age (41 and $49 \mathrm{~cm}$ in core depth); however, these results (viable cysts in supposedly 800 years old sediment) should be considered with caution. Sediment dating estimated using radionuclides $\left({ }^{210} \mathrm{~Pb}_{\mathrm{xs}}\right.$ in the first $32 \mathrm{~cm}$ and ${ }^{14} \mathrm{C}$ from $\left.32 \mathrm{~cm}\right)$ highlights the existence of an erosive surface between the middle of $19^{\text {th }}$ century and middle age in our sediment deposits, which has been reported in other studies in the North Atlantic coastal ocean (Van Vliet et al. 2014 and 2016, Poirier et al. 2017). The origin of this temporal hiatus is inherited from the establishment from 900 to 800 years calibrated before present of a long period of extreme climatic events leading to the construction of dune systems throughout the English Channel coastline and erosion of the shallow coastal seabed (Van Vliet et al. 2014 and 2016, Poirier et al. 2017). In addition to the natural erosion of sediments, development of the port of Brest has occurred since the early 1960s near the sampling zone, which may have increased the erosive surface because of the construction of dikes and deepening of the water basin. The sediments preserved in the upper $25 \mathrm{~cm}$ of our core correspond to the last sedimentary sequence described by Gregoire et al. (2017). The last transgressive deposits are constituted by silty-sand sediments interbedded with red algae bed layers under the combined influence of tidal currents, storm events, and anthropogenic activity. 
These last deposits are stable, as demonstrated by low sedimentation and turbulence rates measured in our core. Given the complex history of sedimentation in the Bay of Brest and the few viable cysts obtained from deep sediments, whether dinoflagellates can be revived from middle age sediments requires further analysis in studies evaluating sediments of multiple centuries. We consider that dinoflagellates can be revived at least in sediments approximately $150 \mathrm{y}$ old. Our observations correspond to the longest survival time reported to date for dinoflagellate cysts and extend the previously observed record ages of maximum viability dated up to a century for Pentapharsodinium dalei (Lundholm et al. 2011), Alexandrium tamarense (Miyazono et al. 2012), and Apocalathium malmogiense (Kremp et al. 2018) and agree with the documented maximal longevity of diatom resting spores and cyanobacterial akinetes (Ellegaard et al. 2018, Ellegaard and Ribeiro 2018).

\section{Biological mechanisms of dormancy and stimulation of germination}

How dinoflagellate cysts could remain viable for such a long time in marine sediments remains unknown. As reviewed by Ellegaard et al. (2018), very little is known about the metabolism of survival in resting stages. Binder and Anderson (1990) have shown that the respiration of cysts of Scrippsiella acuminata (cited as S. trochoidea) was reduced by $90 \%$ compared to that of vegetative stages. Despite such a sharp decrease in metabolic activity, the long-term life of an encysted dinoflagellate may not rely only on internal carbohydrates and stored lipids (Ellegaard and Ribeiro 2018). Resting cysts may rely on external uptake of nutrients during dormancy, as demonstrated for phosphorus in S. acuminata (cited as S. trochoidea in Rengefors et al. 1996). Other biological adaptations to dormancy exist in nature. Some animals can undergo cryptobiosis, a life stage characterized by the depression of metabolic rates to less than $5 \%$ or even reaching complete metabolic shut-down (Withers and Cooper 2010), as reported for Artemia embryos (Clegg 1997). In plants, longevity of seeds can be achieved through transformation of their cytoplasm to a glassy-state, reducing their metabolic activity to a quiescent form (Sano et al. 2015). In addition, highly efficient antioxidant systems and repair mechanisms mitigate the deleterious effects of the oxidation of cellular macromolecules (nucleic acids, proteins, membrane lipids) that occur with ageing and under adverse environmental conditions (Finch-Savage et al. 2006, Long et al. 2015, Sano et al. 2015). Seed coats also provide efficient chemical and physical protection that contributes to seed longevity (Sano et al. 2015). The acquisition of external sources of energy, shift to hypometabolism or ametabolism stages, and existence of protective and repair 
mechanisms may explain the long-time resistance of dormant dinoflagellate stages, but these biological mechanisms require further investigation.

MEL and GA3 successfully promoted the germination of dinoflagellates cysts approximately 150 years old. The beneficial effects of the biostimulants used in this study have been largely described in plants and more specifically in seed germination (e.g., Tirayaki and Keles, 2012, Long et al. 2015). MEL is a pleiotropic molecule used in seed priming to improve germination and resistance to abiotic stress (Posmyk et al. 2009, Tirayaki and Keles 2012, Hernández et al. 2015, Balabusta et al. 2016) and to counteract the loss of viability caused by artificial aging of seeds (Deng et al. 2017a). In plants, MEL undergoes radical detoxification and upregulates antioxidant enzymes, mainly catalase and superoxide dismutase (Kibinza et al. 2011, Zhang et al. 2014, Deng et al. 2017a). Several studies have demonstrated the involvement of MEL in the metabolism of dinoflagellates. In dinoflagellates, MEL was shown to protect against lethal oxidative stress (Antolin et al. 1997), stimulate bioluminescence of Lingulodinium polyedra (Balzer and Hardeland 1989), be involved in the encystment of various species including $S$. acuminata (cited as S. trochoidea in Wong and Wong, 1994), and stimulate the photosynthesis of Symbiodinium (Roopin et al. 2013). The stimulating effect of GA3 on the germination of dormant plant seeds has been widely recognized (Footit et al. 2011, Long et al. 2015). GA3 has not been identified in dinoflagellates, but Stirk et al. (2013) detected and quantified 18-20 different endogenous gibberellins, including the bioactive form GA3, in 24 microalgae strains belonging to the classes Chlorophyceae, Trebouxiophyceae, Ulvophyceae, and Charophyceae by ultraperformance chromatography-tandem mass spectrometry. The growth of Karenia brevis (cited as Gymnodinium breve) and the diatom Cyclotella cryptica were stimulated by external GA3 treatments (Paster and Abott 1970, Adair and Miller 1982). Our results suggest that MEL and GA3 can also play a role in alleviating dormancy and promoting germination even in approximately 150-year-old dormant dinoflagellate cysts.

The biochemical and physiological mechanism of germination stimulation by MEL and GA3 in dinoflagellate resting cysts remains to be explored. Our experiments based on sediment resuspension with different concentrations of biostimulants suggest either an external interaction via specific receptors or active intracellular uptake. In higher plants, the stimulation of germination through volatile compounds has been demonstrated (Flematti et al. 2004). Vegetative cells of dinoflagellates are sensitive to exogenous MEL applications that may involve a $\mathrm{Ca}^{2+}$ 
influx and parallel activation of phospholipase C signaling pathways (Tsim et al. 1998). Although no upregulation of detoxifying enzymes has been demonstrated in dinoflagellates (Antolin et al. 1997), the potential radical oxygen scavenging properties of MEL may help maintain cysts under favorable conditions for germination, increasing their vigor and increasing their germination capacities as observed in plants (Balabusta et al. 2016). However, in our experiments, a high MEL concentration $(1000 \mu \mathrm{M})$ delayed and reduced the germination success of S. acuminata, suggesting a toxic or at least noxious effect of high doses of MEL on dinoflagellate germination. MEL and its homologue, 5-methoxytryptamine, were shown to induce the formation of asexual pellicle cysts in dinoflagellates (Balzer and Hardeland 1992, Wong and Wong 1994), which may be a stress response to MEL. A similar dose-dependent response to exogenous MEL concentrations was reported for maize seedlings, with high melatonin concentrations inhibiting and lower concentrations promoting seedling growth (Zhao et al. 2015). As MEL is also involved in many intracellular signaling pathways (calmodulin, protein kinase $\mathrm{C}$ ), the dose-response of dormancy alleviation and cell germination is complex and remains challenging to evaluate. A putative GA3 receptor (GID1) was identified in S. acuminata (cited as S. trochoidea in Deng et al. 2017b), but GA3 showed no effect on dormancy alleviation in this species. Instead, dormancy induction by abscisic acid was clearly demonstrated (Deng et al. 2017b). The interplay between abscisic acid and GA3 may regulate dormancy and germination in dinoflagellates, which is known to occur in seeds of higher plants (Long et al. 2015).

\section{Implication for resurrection ecology studies}

Beyond the new perspectives in dinoflagellate cellular biology determined in this study, the effect of biostimulants on dormancy alleviation and germination of ancient dinoflagellates offers a new tool for increasing the germination of dinoflagellates from ancient sediments. The relatively low number of revivable strains remains as a limitation to evolutionary ecology studies in the field of resurrection ecology (Weider et al. 2018). Reviving a large number of cells from different ages and cultivating monoclonal strains established from them is vital for obtaining full representatives of the huge genetic and phenotypic diversity of phytoplankton populations, which are sometimes composed of hundreds of thousands of cells (Hinners et al. 2017, Lundholm et al. 2017, Ellegaard et al. 2018). The priming approach in general and use of biostimulants tested in this study in particular may be useful for increasing germination and, potentially, obtaining more dinoflagellate strains from populations of different ages. The stimulation of germination shown in this study may 
further contribute to the development of studies in the field of resurrection ecology and evaluation of patterns in species phenotypic and genomic adaptation in ecosystems that experienced environmental changes over time (Orsini et al. 2013, Lundholm et al. 2017).

\section{ACKNOWLEDGMENTS}

Research funds were provided by the Brittany Region as part of the project PALMIRA (Paleoecology of Alexandrium minutum dans la Rade de Brest-Marché $n^{\circ}$ 2017-90292) which supported the core sampling, analyses, and post-doc fellowship of GD. We thank Arnaud Marrec and Yannick Fagon (Region Bretagne - Service Ingénierie de la Direction des Ports), who allowed the implementation and progression of the project PALMIRA. We are grateful to all members of the crew of the N/O Thalia ship of Ifremer for providing technical expertise in sediment core collection. We thank Angelique Roubi and Jeremie Gouriou of the laboratory GM/LGS of Ifremer for helping during core sampling onboard. The colleagues of the laboratory DYNECO/Pelagos and LER/BO of Ifremer (Francoise Andrieux, Annie Chapelle, Cécile Jauzein, Mickael Le Gac, Kenneth Mertens, Martin Plus, Sophie Schmitt, Agnès Youenou) are acknowledged for their assistance during core subsampling. We thank Julien Quéré of DYNECO/Pelagos for the molecular identification of revived strains, Michel Le Duff of the UMS 3113 for taxonomic identification of gastropod shells used for radiocarbon dating, and Nicolas Chomérat and Kenneth Mertens for their help with taxonomic identification of dinoflagellates. We also thank Amelia Curd for English editing of the manuscript. We are grateful to Malwenn Lassudrie of the laboratory LER/BO for her contribution to the project. Stéphane Lesbats and Olivier Dugornay of Ifremer's Audiovisual Service are thanked for collecting onboard and scuba diving images of the sampling and for producing videos for the project. We certify that there is no conflict of interest with any financial organization regarding the material discussed in this manuscript.

This article is protected by copyright. All rights reserved 


\section{REFERENCES}

Achard, P. and Genschik, P. 2009. Releasing the brakes of plant growth: how gas shutdown DELLA proteins. J. Exp. Bot. 60:1085-92.

Adair, O.V. \& Miller, M.W. 1982. Growth responses of the diatom Cyclotella cryptica (Bacillariophyceae), to gibberellic acid. J. Phycol. 18:587-9

Agrawal, S.C. 2009. Factors affecting spore germination in algae - review. Folia Microbiol. 54:273-302.

Anderson, D.M. 1998. Physiology and bloom dynamics of toxic Alexandrium species, with emphasis on life cycle transitions. In Anderson, D.M., Cembella, A.D. \& Hallegraeff G.M. [Eds.] Physiological Ecology of Harmful Algal Blooms. Springer, Berlin Heidelberg, pp.29-48.

Anderson, D. M. \& Keafer, B. A. 1987. An endogenous annual clock in the toxic marine dinoflagellate Gonyaulax tamarensis. Nature 315:616-17.

Anderson, D.M. \& Rengefors, K. 2006. Community assembly and seasonal succession of marine dinoflagellates in a temperate estuary: The importance of life cycle events. Limnol. Oceanogr. $51: 860-73$.

Anderson, D.M., Taylor, C.D. \& Armbrust, E.V. 1987. The effects of darkness and anaerobiosis on dinoflagellate cyst germination. Limnol. Oceanogr. 32:340-51.

Anderson, R.A., Berges, R.A., Harrison, P.J. \& Watanabe, M.M. 2005. Appendix A - Recipes for Freshwater and Seawater Media; Enriched Natural Seawater Media. In Andersen, R.A., [Ed.] Algal Culturing Techniques. Academic, San Diego, USA, pp. 429-538.

Andrisano, V., Bertucci, C., Battaglia, A. \& Cavrini, V. 2000. Photostability of drugs: photodegradation of melatonin and its determination in commercial formulations. J. Pharm. Biomed. Anal. 23:15-23.

Angeler, D.G. 2007. Resurrection ecology and global climate change research in freshwater ecosystems. J. North Am. Benthol. Soc. 26:12-22. 
Antolín, I., Obst, B., Burkhardt, S. \& Hardeland, R. 1997. Antioxidative protection in a highmelatonin organism: The dinoflagellate Gonyaulax polyedra is rescued from lethal oxidative stress by strongly elevated, but physiologically possible concentrations of melatonin. J. Pineal Res. 23:182-90.

Arnao, M.B. \& Hernández-Ruiz, J. 2014. Melatonin: Plant growth regulator and/or biostimulator during stress? Trends Plant Sci. 19:789-97.

Balabusta, M., Szafranska, K. \& Posmyk, M.M. 2016. Exogenous melatonin improves antioxidant defense in Cucumber seeds (Cucumis sativus L.) germinated under chilling stress. Front. Plant Sci. $7: 575$

Balzer, I. \& Hardeland, R. 1989. Action of kynuramine in a dinoflagellate: Stimulation of bioluminescence in Gonyaulax polyedra. Comp. Biochem. Physiol. Part C Comp. 94:129-32.

Balzer, I. \& Hardeland, R. 1992. Effects of indoleamines and short photoperiods on the encystment of Gonyaulax polyedra. Chronobiol. Int. 9:260-5.

Balzer, I., \& Hardeland, R. 1996. Melatonin in algae and higher plants-possible new roles as a phytohormone and antioxidant. Plant Biol. 109:180-3.

Barba-Espin, G., Diaz-Vivancos, P., Clemente-Moreno, M.J., Albacete, A., Faize, L., Faize, M., Pérez-Alfocea, F. \& Hernández, J.A. 2010. Interaction between hydrogen peroxide and plant hormones during germination and the early growth of pea seedlings. Plant Cell Environ. 33:98194.

Biddington, N.L. \& Thomas, T.H. 1976. Influence of different cytokinins on germination of lettuce (Lactuca sativa) and celery (Apium graveolens) seeds. Physiol. Plant. 37:12-6.

Binder, B.J. \& Anderson, D.M. 1986. Green light-mediated photomorphogenesis in a dinoflagellate resting cyst. Nature 322:659-61.

Binder, B. J. \& Anderson, D. M. (1990). Biochemical composition and metabolic activity of Scrippsiella trochoidea (Dinophyceae) resting cysts. J. Phycol. 26:289-98. 
Brede, N., Sandrock, C., Straile, D., Spaak, P., Jankowski, T., Streit, B. \& Schwenk, K. 2009. The impact of human-made ecological changes on the genetic architecture of Daphnia species. Proc. Natl. Acad. Sci. USA 106:4758-63.

Caceres, C.E. \& Tessier, A.J. 2003. How long to rest: the ecology of optimal dormancy and environmental constraint. Ecology 84:1189-98.

Clegg, J.S. 1997. Embryos of Artemia franciscana survive four years of continuous anoxia: the case for complete metabolic rate depression. J. Exp. Biol. 200:467-75.

Costas, E., Gil, S.G., Aguilera, A. \& Rodas, V.L. 1993. An apparent growth factor modulation of marine dinoflagellate excystment. J. Exp. Mar. Bio. Ecol. 166:241-9.

Dale, B., Thorsen, T.A. \& Fjellså, A. 1999. Dinoflagellate cysts as indicators of cultural eutrophication in the Oslofjord, Norway. Estuar. Coast. Shelf Sci. 48:371-82.

Deng, B., Yang, K., Zhang, Y. \& Li, Z. 2017a. Can antioxidant's reactive oxygen species (ROS) scavenging capacity contribute to aged seed recovery? Contrasting effect of melatonin, ascorbate and glutathione on germination ability of aged maize seeds. Free Radic. Res. 51:765-71.

Deng, Y., Hu, Z., Shang, L., Peng, Q. \& Tang, Y.Z. 2017b. Transcriptomic analyses of Scrippsiella trochoidea reveals processes regulating encystment and dormancy in the life cycle of a dinoflagellate, with a particular attention to the role of abscisic acid. Front. Microbiol. 8:1-19.

Dumont, H.J., Casier, P., Munuswamy, N. \& De Walsche, C. 1992. Cyst hatching in Anostraca accelerated by retinoic acid, amplified by Calcium Ionophore A23187, and inhibited by Calciumchannel blockers. Hydrobiologia 230:1-7.

Ellegaard, M., Moestrup, Ø., Andersen, T.J. \& Lundholm, N. 2016. Long-term survival of haptophyte and prasinophyte resting stages in marine sediment. Eur. J. Phycol. 51:328-37.

Ellegaard, M., Godhe, A. \& Ribeiro, S. 2018. Time capsules in natural sediment archivesTracking phytoplankton population genetic diversity and adaptation over multidecadal timescales in the face of environmental change. Evol. Appl. 11:11-6.

Ellegaard, M. \& Ribeiro, S. 2018. The long-term persistence of phytoplankton resting stages in aquatic 'seed banks'. Biol. Rev. 93:166-83. 
Feifel, K.M., Fletcher, S.J., Watson, L.R., Moore, S.K. \& Lessard, E.J. 2015. Alexandrium and Scrippsiella cyst viability and cytoplasmic fullness in a 60-cm sediment core from Sequim Bay, WA. Harmful Algae 47:56-65.

Finch-Savage, W.E. \& Leubner-Metzger, G. 2006. Seed dormancy and the control of germination. New Phytol. 171:501-23.

Finkelstein, R., Reeves, W., Ariizumi, T. \& Steber, C. 2008. Molecular aspects of seed dormancy. Annu. Rev. Plant Biol. 59:387-415.

Fischer, A.D., Brosnahan, M.L. \& Anderson, D.M. 2018. Quantitative response of Alexandrium catenella cyst dormancy to cold exposure. Protist 169: 645-61.

Flematti, G.R., Ghisalberti, E.L., Dixon, K.W. \& Trengove, R.D. 2004. A compound from smoke that promotes seed germination. Science 80:305:977.

Footitt, S., Douterelo-Soler, I., Clay, H. \& Finch-Savage, W.E. 2011. Dormancy cycling in Arabidopsis seeds is controlled by seasonally distinct hormone-signaling pathways. Proc. Natl. Acad. Sci. USA 108:20236-41.

Gregoire, G., Le Roy, P., Ehrhold, A., Jouet, G. \& Garlan, T. 2017. Control factors of Holocene sedimentary infilling in a semi-closed tidal estuarine-like system: the bay of Brest (France). Mar. Geol. 385:84-100.

Groot, S.P.C. \& Karssen, C.M. 1987. Gibberellins regulate seed germination in tomato by endosperm weakening: a study with GA-deficient mutants. Planta 171:525-31.

Hagiwara, A., Hoshi, N., Kawahara, F., Tominaga, K. \& Hirayama, K. 1995. Resting eggs of the marine rotifer Brachionus plicatilis Miller: development and effect of irradiation on hatching. Hydrobiologia 313/314:223-9.

Hairston, N.G., Kearns, Jr \& Kearns, C.M. 2002. Temporal dispersal: ecological and evolutionary aspects of zooplankton egg banks and the role of sediment mixing. Integr. Comp. Biol. 42:481-91.

Hallegraeff, G.M., Marshall, J.A., Valentine, J. \& Hardiman, S. 1998. Short cyst-dormancy period of an Australian isolate of the toxic dinofiagellate Alexandrium catenella. Mar. Freshw. Res. 49:415-20. 
Hardeland, R. \& Poeggeler, B. 2003. Non-vertebrate melatonin. J. Pineal Res. 34:233-41.

Harnstrom, K., Ellegaard, M., Andersen, T.J. \& Godhe, A. 2011. Hundred years of genetic structure in a sediment revived diatom population. Proc. Natl. Acad. Sci. USA 108:4252-7.

Hernández, I.G., Gomez, F.J.V., Cerutti, S., Arana, M.V. \& Silva, M.F. 2015. Melatonin in Arabidopsis thaliana acts as plant growth regulator at low concentrations and preserves seed viability at high concentrations. Plant Physiol. Biochem. 94:191-6.

Hinners, J., Kremp, A. \& Hense, I. 2017. Evolution in temperature-dependent phytoplankton traits revealed from a sediment archive: do reaction norms tell the whole story? P. Roy. Soc. B 284 : 20171888.

Houwenhuyse, S., Macke, E., Reyserhove, L., Bulteel, L. \& Decaestecker, E. 2018. Back to the future in a petri dish: Origin and impact of resurrected microbes in natural populations. Evol. Appl. $11: 29-41$.

Ibrahim, E.A. 2016. Seed priming to alleviate salinity stress in germinating seeds. J. Plant Physiol. $192: 38-46$.

Ishikawa, A. \& Taniguchi, A. 1996. Contribution of benthic cysts to the population dynamics of Scrippsiella spp. (Dinophyceae) in Onagawa Bay, northeast Japan. Mar. Ecol. Prog. Ser. 140:16978.

Kawahara, M., Ohtsu, K. \& Uye, S.I. 2013. Bloom or non-bloom in the giant jellyfish Nemopilema nomurai (Scyphozoa: Rhizostomeae): Roles of dormant podocysts. J. Plankton Res. $35: 213-7$.

Kibinza, S., Bazin, J., Bailly, C., Farrant, J.M., Corbineau, F. \& El-Maarouf-Bouteau, H. 2011. Catalase is a key enzyme in seed recovery from ageing during priming. Plant Sci. 181:309-15.

Kim, Y. O. \& Han, M. S. 2000. Seasonal relationships between cyst germination and vegetative population of Scrippsiella trochoidea (Dinophyceae). Mar. Ecol. Prog. Ser. 204:111-8.

Kim, Y. O., Park, M. H. \& Han, M. S. 2002. Role of cyst germination in the bloom initiation of Alexandrium tamarense (Dinophyceae) in Masan Bay, Korea. Aquat. Microb. Ecol. 29:279-86. 
Klouch, K., Schmidt, S., Andrieux-Loyer, F., Le Gac, M., Hervio-Heath, D., Qui-Minet, Z., Quéré, J., Bigeard, E., Guillou, L. \& Siano, R. 2016a. Historical records from dated sediment cores unveiled the multidecadal dynamics of the toxic dinoflagellate Alexandrium minutum in the Bay of Brest (France). FEMS Microbiol. Ecol. 92:1-51.

Klouch, K., Caradec, F., Plus, M., Hernandez-Farinas, T., Pineau-Guillou, L., Chapelle, A., Schmitt, S., Quere, J., Guillou, L. \& Siano, R. 2016b. Heterogeneous distribution in sediments and dispersal in waters of Alexandrium minutum in a semi-enclosed coastal ecosystem . Harmful Algae 60: 81-91.

Kremp, A., Hinners, J., Klais, R., Leppänen, A.P. \& Kallio, A. 2018. Patterns of vertical cyst distribution and survival in 100-year-old sediment archives of three spring dinoflagellate species from the Northern Baltic Sea. Eur. J. Phycol. 53:135-45.

Kretschmann, J., Elbrächter, M., Zinssmeister, C., Soehner, S., Kirsch, M., Kusber, W. H. \& Gottschling, M. 2015. Taxonomic clarification of the dinophyte Peridinium acuminatum Ehrenberg, = Scrippsiella acuminata , comb. nov. (Thoracosphaeraceae, Peridiniales). Phytotaxa 220: $239-56$.

Lavens, P. \& Sorgeloos, P. 1987. The cryptobiotic state of Artemia cysts, its diapause deactivation and hatching: a review. In Sorgeloos, P. Bengston, D. A., Decleir, W. \& Jaspers, E. [Eds.] Artemia Research and its Applications. Vol. 3. Ecology, culturing, use in Aquaculture. Universa Press, Wetteren, Belgium, pp. 27-63.

Long, R.L., Gorecki, M.J., Renton, M., Scott, J.K., Colville, L., Goggin, D.E., Commander, L.E., Westcott, D.A., Cherry, H. \& Finch-Savage, W.E. 2015. The ecophysiology of seed persistence: a mechanistic view of the journey to germination or demise. Biol. Rev. 90:31-59.

Lopez, C.B., Karim, A., Murasko, S., Marot, M.E., Smith, C.G. \& Corcoran, A.A. 2019. Temperature mediates secondary dormancy in resting cysts of Pyridinium bahamense (Dinophyceae). J. Phycol. 55:924-35.

Lundholm, N., Ribeiro, S., Andersen, T.J., Koch, T., Godhe, A., Ekelund, F. \& Ellegaard, M. 2011. Buried alive - germination of up to a century-old marine protist resting stages. Phycologia. 50:629-40. 
Lundholm, N., Ribeiro, S., Godhe, A., Nielsen, L.R. \& Ellegaard, M. 2017. Exploring the impact of multidecadal environmental changes on the population genetic structure of a marine primary producer. Ecol Evol. 7:3132-42.

Matrai, P., Thompson, B. \& Keller, M. 2005. Circannual excystment of resting cysts of Alexandrium spp. from eastern Gulf of Maine populations. Deep. Res. Part II Top. Stud. Oceanogr. 52:2560-8.

McQuoid, M.R., Godhe, A. \& Nordberg, K. 2002. Viability of phytoplankton resting stages in the sediments of a coastal Swedish fjord. Eur. J. Phycol. 37:191-201.

Miyazono, A., Nagai, S., Kudo, I. \& Tanizawa, K. 2012. Viability of Alexandrium tamarense cysts in the sediment of Funka Bay, Hokkaido, Japan: Over a hundred year survival times for cysts. Harmful Algae 16:81-8.

Montresor, M. \& Marino D., 1996. Modulating effect of cold-dark storage on excystment in Alexandrium pseudogonyaulax (Dinophyceae). Mar. Biol. 127:55-60.

Nakamura, T., Kawanabe, Y., Takiyama, E., Takahashi, N. \& Murayama, T. 1978. Effects of auxin and gibberellin on conidial germination in Neurospora crassa. Plant Cell Physiol. 19:705-9.

Née, G., Xiang, Y. \& Soppe, W.J. 2017. The release of dormancy, a wake-up call for seeds to germinate. Curr. Opin. Plant Biol. 35:8-14.

Nikolić, R., Mitić, N., Miletić, R. \& Nešković, M. 2006. Effects of cytokinins on in vitro seed germination and early seedling morphogenesis in Lotus corniculatus L. J. Plant Growth Regul. 25:187-94.

Ogawa, K. \& Iwabuchi, M. 2001. Mechanism for promoting the germination of Zinnia elegans seeds by hydrogen peroxide. Plant Cell Physiol. 42:286-91.

Orsini, L., Schwenk, K., De Meester, L., Colbourne, J.K., Pfrender, M.E. \& Weider, L.J. 2013. The evolutionary time machine: Using dormant propagules to forecast how populations can adapt to changing environments. Trends Ecol. Evol. 28:274-82.

Paster, Z. \& Abbott, B.C. 1970. Gibberellic acid: a growth factor in the unicellular alga Gymnodinium breve. Science 169:600-1. 
Perez, C. C., Roy, S., Levasseur, M. \& Anderson, D. M. 1998. Control of germination of Alexandrium tamarense (Dinophyceae) cysts from the lower St. Laurence estuary (Canada). J. Phycol. 34:242-49.

Perez, R., Wörmer, L., Sass, P. \& Maldener, I. 2017. A highly asynchronous developmental program triggered during germination of dormant akinetes of the filamentous diazotrophic cyanobacteria. FEMS Microbiol. Ecol. 94 : fix131.

Poirier, C., Tessier, B., Chaumillon, E., Bertin X., Fruergaard, M., Mouazé, D., Noël, S., Weill, P. \& Woppelmann, G. 2017. Decadal changes in North Atlantic atmospheric circulation patterns recorded by sand spits since 1800 CE. Geomorphology 281:1-12.

Poeggeler, B., Balzer, I., Hardeland, R. \& Lerchl, A. 1991. Pineal hormone melatonin oscillates also in the dinoflagellate Gonyaulax polyedra. Sci. Nat. 78:268-9.

Posmyk, M.M., Bałabusta, M., Wieczorek, M., Sliwinska, E. \& Janas, K.M. 2009. Melatonin applied to cucumber (Cucumis sativus L.) seeds improves germination during chilling stress. $J$. Pineal Res. 46:214-23.

Radzikowski, J. 2013. Resistance of dormant stages of planktonic invertebrates to adverse environmental conditions. J. Plankton Res. 35:707-23.

Reimer, P.J., Bard, E., Bayliss, A., Beck, J.W., Blackwell, P.G., Ramsey, C.B., Buck, C.E., Cheng, H., Edawards, R.L., Friedrich, M., Grootes, P.M., Guilderson, T.P., Haflidason, H., Hajdas, I., Hatté, H., Heaton, T.J., Hoffmann, D.L., Hogg, A.G., Hughen, K.A., Kaiser, K.F., Kromer, B., Manning, S.W., Niu, M., Reimer, R.W., Richards, D.A., Scott, E.M., Southon, J.R., Staff, R.A., Turney, C.S.M. \& van der Plicht, J. 2013. IntCal13 and Marine13 radiocarbon age calibration curves 0-50,000 years cal BP. Radiocarbon 55:1869-87.

Rengefors, K., Anderson, D.M. \& Pettersson, K. 1996. Phosphorus uptake by resting cysts of the marine dinoflagellate Scrippsiella trochoidea. J. Plankton Res. 18:1753-65.

Rengefors, K. \& Anderson, D.M. 1998. Environmental and endogenous regulation of cyst germination in two freshwater dinoflagellates. J. Phycol. 34:568-77.

Robbins, H.M., Van Stappen, G., Sorgeloos, P., Sung, Y.Y., MacRae, T.H. \& Bossier, P. 2010. 
Diapause termination and development of encysted Artemia embryos: roles for nitric oxide and hydrogen peroxide. J. Exp. Biol. 213:1464-70.

Roopin, M., Yacobi, Y.Z. \& Levy, O. 2013. Occurrence, diel patterns, and the influence of melatonin on the photosynthetic performance of cultured Symbiodinium. J. Pineal Res. 55:89-100.

Sano, N., Rajjou, L., North, H.M., Debeaujon, I., Marion-Poll, A. \& Seo, M. 2016. Staying alive: molecular aspects of seed longevity. Plant Cell Physiol. 57:660-74.

Sanyal, A., Larsson, J., van Wirdum, F., Andrén, T., Moros, M., Lönn, M. \& Andrén, E. 2019. Not dead yet: diatom resting spores can survive in nature for several millennia. BioRxiv http://dx.doi.org/10.1101/285122.

Schmidt, S., Jouanneau, J.M., Weber, O., Lecroart, P., Radakovitch, O., Gilbert, F. \& Jézéquel, D. 2007. Sedimentary processes in the Thau Lagoon (France): From seasonal to century time scales. Estuar. Coast. Shelf Sci. 72:534-42.

Shikata, T., Iseki, M., Matsunaga, S., Higashi, S.I., Kamei, Y. \& Watanabe, M. 2011. Blue and red light-induced germination of resting spores in the red-tide diatom Leptocylindrus danicus. Photochem. Photobiol. 87:590-7.

Simpson, T.L. \& Fell, P.E. 1974. Dormancy among the Porifera: gemmule formation and germination in fresh-water and marine sponges. Trans. Am. Microsc. Soc. 93:544-77.

Steinhardt, R.A. \& Epel, D. 1974. Activation of sea-urchin eggs by a calcium ionophore. Proc. Natl. Acad. Sci. USA 71:1915-9.

Stirk, W.A., Bálint, P., Tarkowská, D., Novák, O., Strnad, M., Ördög, V. \& van Staden, J. 2013. Hormone profiles in microalgae: Gibberellins and brassinosteroids. Plant Physiol. Biochem. 70:348-53.

Stirk, W.A., Bálint, P., Tarkowská, D., Novák, O., Maróti, G., Ljung, K., Turečková, V., Strnad, M., Ördög, V.\& van Staden, J. 2014. Effect of light on growth and endogenous hormones in Chlorella minutissima (Trebouxiophyceae). Plant Physiol. Biochem. 79:66-76.

Stuiver, M. \& Reimer, P.J. 1993. Extended ${ }^{14} \mathrm{C}$ data base and revised CALIB $3.0{ }^{14} \mathrm{C}$ age calibration program. Radiocarbon 35:215-30. 
Tisnérat-Laborde, N., Paterne, M., Métivier, B., Arnold, M., Yiou, P., Blamart, D. \& Raynaud, S. 2010. Variability of the northeast Atlantic sea surface $\Delta^{14} \mathrm{C}$ and marine reservoir age and the North Atlantic Oscillation (NAO). Quat. Sci. Rev. 29: 2633-46.

Tiryaki, I. \& Keles, H. 2012. Reversal of the inhibitory effect of light and high temperature on germination of Phacelia tanacetifolia seeds by melatonin. J. Pineal Res. 52:332-9.

Tsavkelova, E.A., Cherdyntseva, T.A., Klimova, S.Y., Shestakov, A.I., Botina, S.G. \& Netrusov, A.I. 2007. Orchid-associated bacteria produce indole-3-acetic acid, promote seed germination, and increase their microbial yield in response to exogenous auxin. Arch. Microbiol. 188:655-64.

Tsim, S.T., Wong, J.T.Y. \& Wong, Y.H. 1998. Regulation of calcium influx and phospholipase C activity by indoleamines in dinoflagellate Crypthecodinium cohnii. J. Pineal Res. 24:152-61.

Van Vliet-Lanoë, B., Penaud, A., Hénaff, A., Delacourt, C., Fernane, A., Goslin, J., Hallégouët, B. \& Le Cornec, E. 2014. Middle- to late-Holocene storminess in Brittany (NW France): Part II The chronology of events and climate forcing. Holocene 24:434-53.

Van Vliet-Lanoë, V., Goslin, J., Hénaff, A., Hallégouet, B., Delacourt, C., Le Cornec, E. \& Meurisse-Fort, M. 2016. Holocene formation and evolution of coastal dunes ridges, Brittany (France). Comptes Rendus Geoscience 348:462-70.

Verni, F. \& Rosati, G. 2011. Resting cysts: A survival strategy in Protozoa Ciliophora. Ital. J. Zool. 78:134-45.

Weider, L.J., Jeyasingh, P.D. \& Frisch, D. 2018. Evolutionary aspects of resurrection ecology: Progress, scope, and applications-An overview. Evol. Appl. 11:3-10.

White, T.J., Bruns , T., Lee, S. \& Taylor, J. 1990. Amplification and direct sequencing of fungal ribosomal RNA genes for phylogenetics. In Innis, M.A., Gelfand, D.H., Sninsky, J.J., [Eds.] PCR Protocols: A Guide to Methods and Applications. San Diego, Academic Press pp. 315-322.

Withers, P. C. \& Cooper, C. E. 2010. Metabolic depression: a historical perspective. In Navas, C.A. \& Carvalho, J.E. [Eds.] Aestivation: Molecular and Physiological Aspects, Progress in Molecular and Subcellular Biology. Springer, Berlin-Heidelberg, pp. 1-23.

Wong, J.T.Y. \& Wong, Y.H. 1994. Indoleamines induced encystment in dinoflagellates. J. Mar. 
Biol. Assoc. UK 74:467-9.

Yamamoto, Y. 1976. Effect of some physical and chemical factors on the germination of akinetes of Anabaena cylindrica. J. Gen. Appl. Microbiol. 22:311-323.

Zhang, Y.X. \& Lespinasse, Y. 1991. Removal of embryonic dormancy in apple (Malus $\times$ domestica Borkh) by 6-benzylaminopurine. Sci. Hortic. 46:215-23.

Zhang, H.J., Zhang, N., Yang, R.C., Wang, L., Sun, Q.Q., Li, D.B., Cao, Y.Y., Weeda, S., Zhao, B., Ren, S. \& Guo, Y. D. 2014. Melatonin promotes seed germination under high salinity by regulating antioxidant systems, $\mathrm{ABA}$ and $\mathrm{GA}_{4}$ interaction in cucumber (Cucumis sativus L.). J. Pineal Res. 57:269-79.

Zhao, H., Su, T., Huo, L., Wei, H., Jiang, Y., Xu, L. \& Ma, F. 2015. Unveiling the mechanism of melatonin impacts on maize seedling growth: sugar metabolism as a case. J. Pineal Res. 59:25566. 
Table 1: Examples of chemicals used to accelerate or enhance cysts germination or egg hatching.

Stimulation method

Retinoic acid, Calcium ionophore A23187

\section{Calcium ionophore A23187}

Echinodermata

Strongilocentrotus

purpuratus

Diatom

Plantae

Plantae

Plantae

Plantae

Fungi/Ascomy

cota
Lytechinus picnus

Reference

Dumont et al. 1992

Streptocephalus dichotomus

Steinhardt and Epel

1974

Shikata et al. 2011

Tiryaki and Keles 2012

Posmyk et al. 2009

Deng et al. 2017a

Hernández et al. 2015

Nakamura et al. 1978

\section{Auxin (IAA)}

Plantae

Dendrobium moschatum

Tsavkelova et al. 2007 
Gibberellin (GA)

Hydrogen peroxid
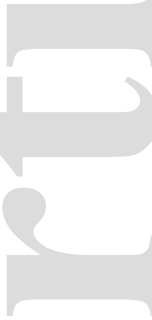

Hydrogen peroxid,

Prostaglandin

Hydrogen peroxide, Nitric oxide

6-Benzylaminopurine

(cytokinin)

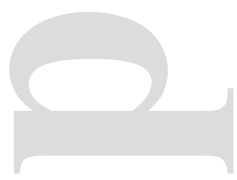

Plantae

Plantae

Plantae

Malus x domestica

Lotus corniculatus

Lactuca sativa

Alexandrium tamarense

Costas et al. 1993

Acetate

Cyanophyta
Anabena cylindrica
Groot and Karssen 1987

Ogawa and Iwabuchi 2001

Barba-Espin et al. 2010

Hagiwara et al. 1995

Robbins et al. 2010

Zhang and Lespinasse 1991

Nikolic et al. 2006

Biddington and Thomas 1976 
Figure 1: ${ }^{210} \mathrm{Pbxs}(\mathrm{A})$ and ${ }^{137} \mathrm{Cs}(\mathrm{C})$ profiles in the core KS03. Core chronology $(\mathrm{B})$ based on ${ }^{210} \mathrm{Pbxs}$ dating and associated age model uncertainty at $\pm 1 \mathrm{SD}$. The arrow underlines the expected onset in the early 1950 s of artificial 137 Cs.

Figure 2: Summary of dinoflagellate taxa successful germinations obtained with control and/or stimulated germination with $100 \mu \mathrm{M}$ and $1000 \mu \mathrm{M}$ concentrations of melatonin and gibberellic acid as a function of core depth. Dating (Years) of sediment layers calculated with excess ${ }^{210} \mathrm{~Pb}$ are indicated on the left of the figure. The taxa: Alexandrium minutum, Heterocapsa minima, Margalefidinium polykrikoides, Protoperidinium spp., Diplopsalis group, undet. Gymnodiniales $20<\mathrm{x}<50 \mu \mathrm{m}$, unknown autotroph and unknown heterotroph were identified morphologically. The species Scrippsiella acuminata was identified both morphologically and by Sanger sequencing of established cultures.

Figure 3: Number of successful germination per well observed after $28 \mathrm{~d}$ under control conditions and various concentrations of melatonin and gibberellic acid in sediments dated to $117 \pm 21 \mathrm{y}$. Results are presented for Scrippsiella acuminata, Protoperidinum spp., the Diplopsalid group and for all other dinoflagellate taxa. The number of experimental wells used was 20 for all conditions except for the control for which 36 experimental wells were used. Scrippsiella acuminata was identified both morphologically and by Sanger sequencing of established cultures. The taxa Protoperidinium spp., Diplopsalis group as well as the other dinoflagellates included in this analysis were identified only morphologically.

Figure 4: Cumulative percentage of germinated wells for Scrippsiella acuminata from sediments dated back to $117 \pm 21 \mathrm{y}$.

Figure S1: Lithological description of selected gravity-cores for this study. Due to the slice operation every centimeter, the lithology of the $\mathrm{KS} 03$ core is described at the time of the sediment 
subsampling. The correlations between sediments facies are possible with the neighboring core (KS01) and the farther away core (KS05) which have been fully analyzed in their continuity.

Table S1: ${ }^{14} \mathrm{C}$ radiocarbon dating used for this study.

Table S2: Effect of melatonin (MEL) and gibberellic acid (GA3) treatment on germinations of identified dinoflagellate taxa from sediment dated to $117 \pm 21 \mathrm{y}$. Results are expressed in percentage (number of taxon germinations /total number of observed germinations $\mathrm{x} 100$ ). Experimental incubation lasted $28 \mathrm{~d}$. 


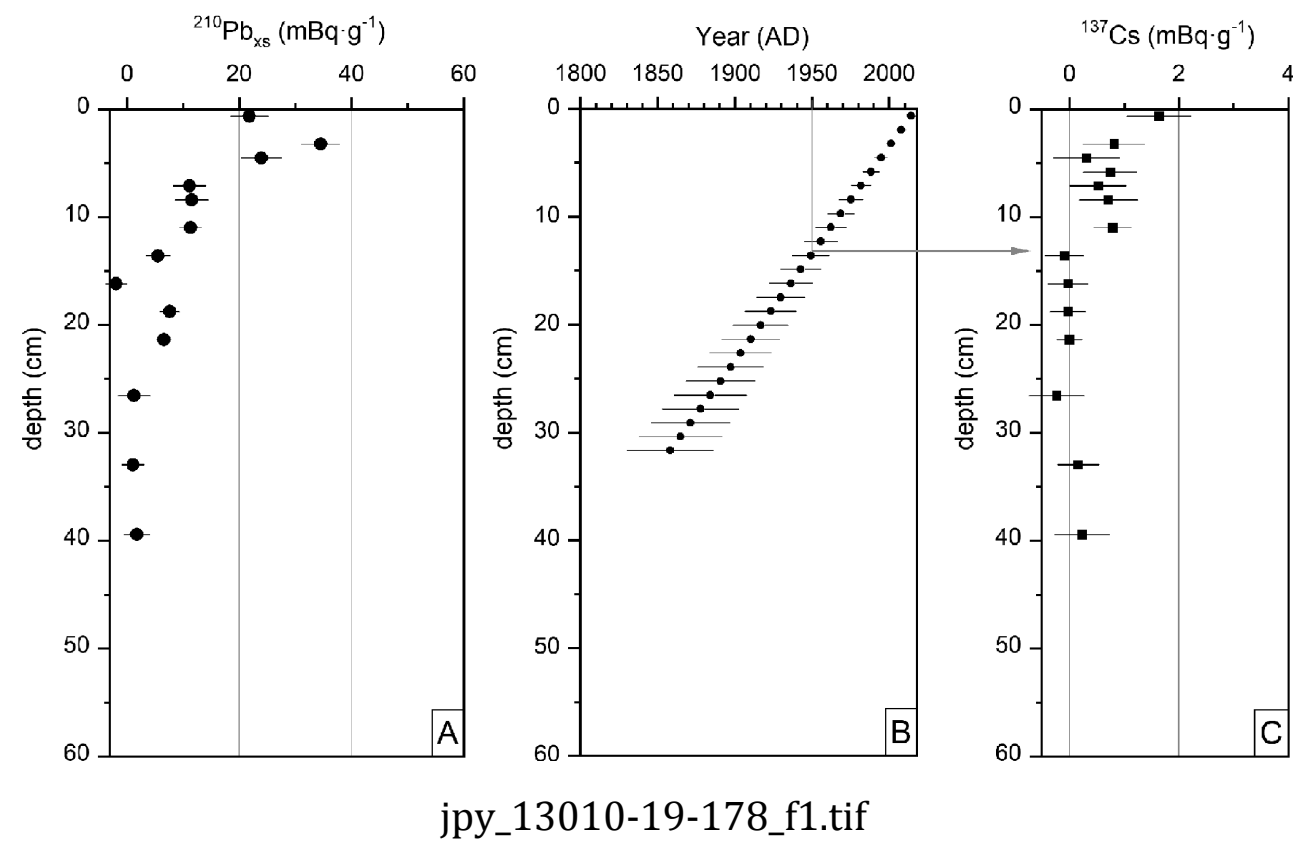

This article is protected by copyright. All rights reserved 


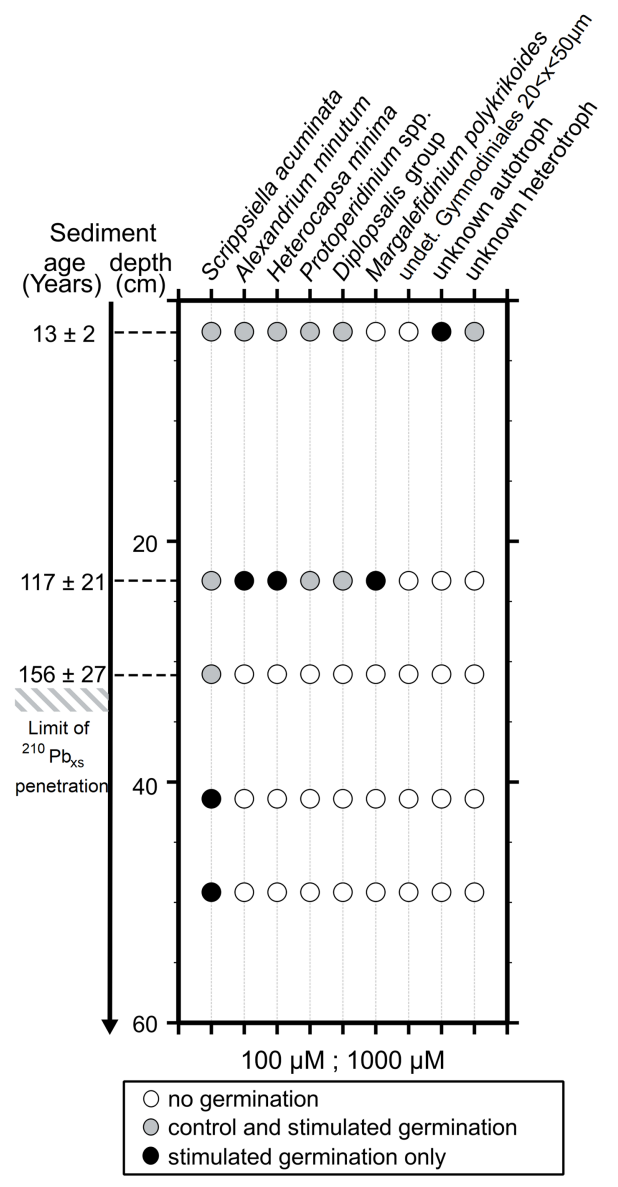

jpy_13010-19-178_f2.tif 

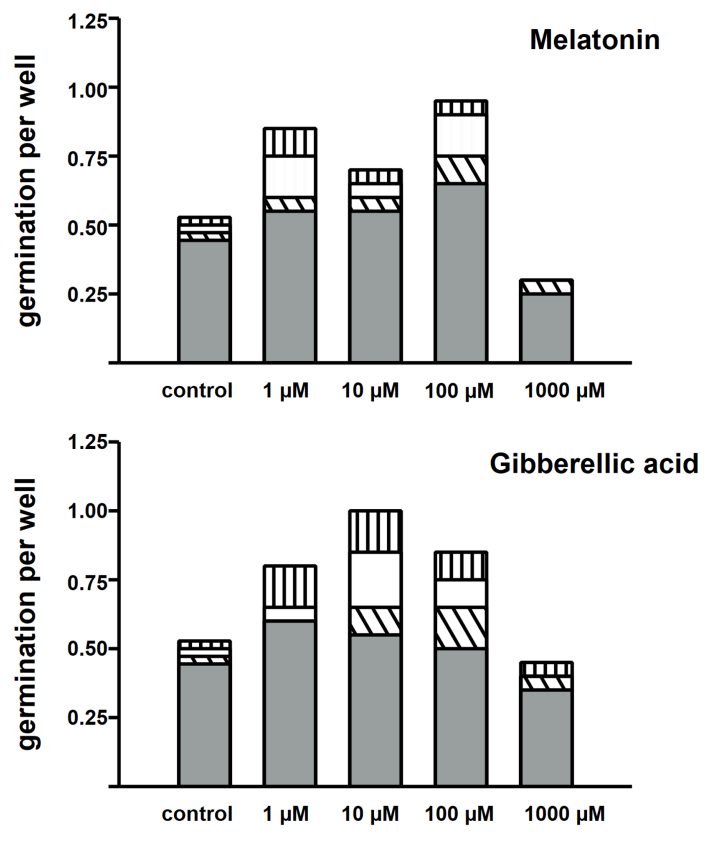

\begin{tabular}{|llll}
\hline & $\begin{array}{l}\text { Scrippsiella acuminata } \\
\text { Protoperidinium spp. }\end{array}$ & $\square$ & Diplopsalis group \\
OW & Other dinoflagellates
\end{tabular}

jpy_13010-19-178_f3.tif 

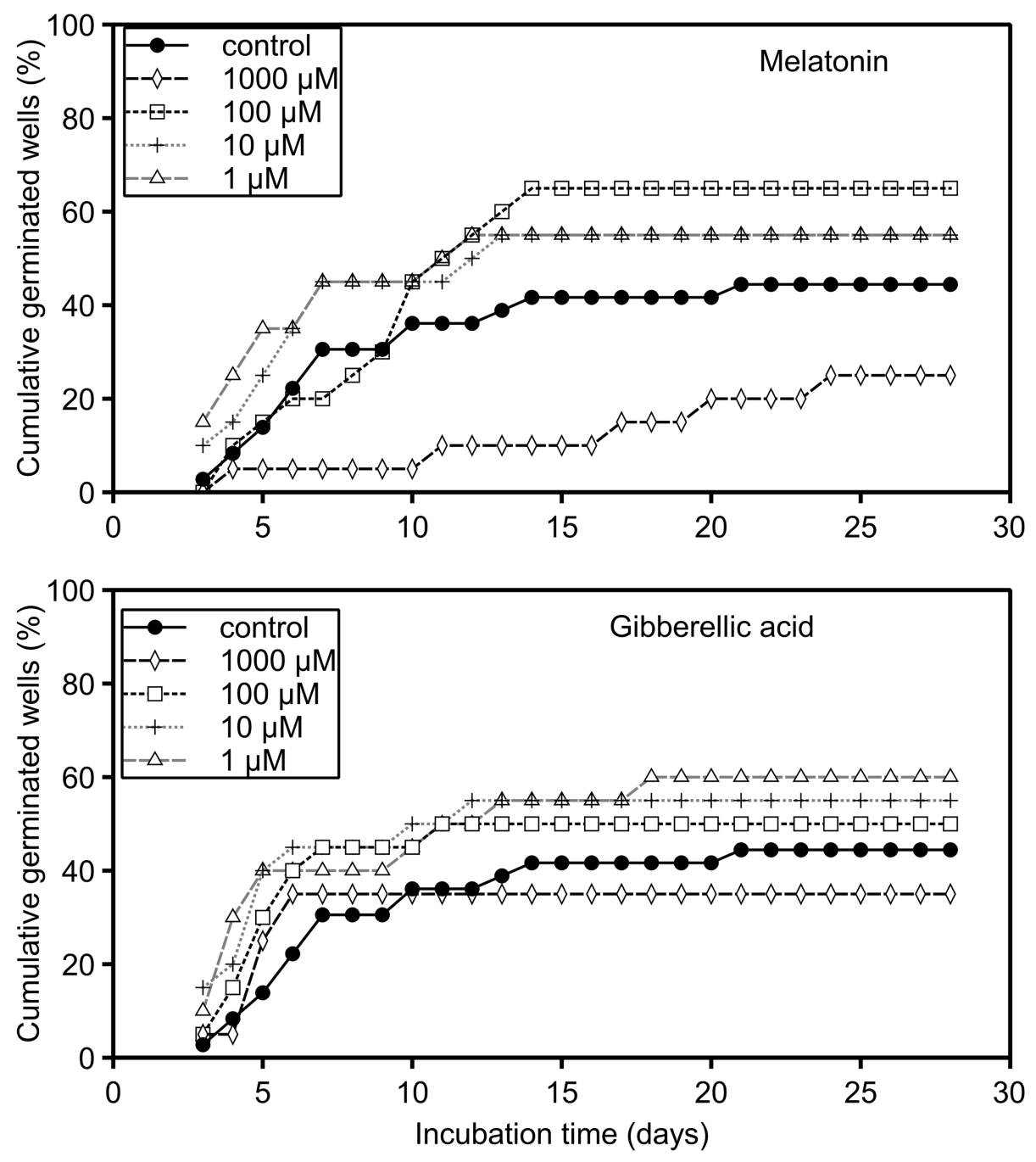

jpy_13010-19-178_f4.tif

This article is protected by copyright. All rights reserved 